\title{
AN ANALYSIS OF THE VISUAL PORTRAYAL OF WOMEN IN JUNIOR SECONDARY MALAWIAN SCHOOL HISTORY TEXTBOOKS
}

\author{
DOI: http://dx.doi.org/10.17159/2223-0386/2015/n14a9
}

Annie Chiponda

Chancellor College

University of Malawi, Zomba, Malawi

bulalaann@gmail.com
Johan Wassermann

School of Education

University of KwaZulu-Natal, South Africa

wassermannj@ukzn.ac.za

\section{Abstract}

Visual images are important in textbooks because they are a vital part of the symbiotic relationship with the written text. Most importantly, visual images are essential in history textbooks because they render human experiences less abstract. This article analyses the visual images of women contained in three junior secondary school history textbooks used in Malawi. The purpose being to explore how women are portrayed visually and why they are portrayed the way they are. The article is based on empirical research and employed feminist theory which is premised on the oppression and subordination of women in society. The visual images were analysed quantitatively through visual content analysis and qualitatively using visual semiotic analysis. We argue in this article that women are generally oppressed, under-represented and subordinated in their portrayal in the visual images in the textbooks analysed. As textbooks are authoritative in nature this kind of portrayal can send a certain message about women as historical characters to textbook users. We furthermore argue that our research findings in an African context speak to similar findings in other parts of the world and can for the most part be attributed to similar reasons - the powerful influences of patriarchy on both history and history textbooks.

Keywords: Visual images; History textbooks; Women; Feminism; Content analysis; Semiotic analysis.

\section{Introduction}

An old adage has it that a picture is worth a thousand words. Another has it that seeing is believing. What can be gleaned from these two sayings is that visual images - for the purpose of this article we regard paintings, drawings, photos, cartoons, posters, pictures and any other visual depiction as a visual image - are powerful means of communication. This is also the case with history textbooks as visual images are important in its symbiotic interaction 
with the written text while simultaneously rendering the abstract nature of the subject more concrete.

Visual images have over the recent decades gained more prominence as the world has in many ways taken a visual turn and many people, including teachers and learners, are no longer experiencing written text as having supremacy over visual images (Harrison, 2003:46-60). Rather, they absorb and process all the visual images they see within a text to create meanings for themselves. In the process visual images tend to articulate more forcefully social and cultural meanings than the written text (Berger, 1989:1-23). In this regard it is a truism that visual images are no longer included in history textbooks merely for decorative purposes but they serve an important educational purpose (Zeegen, 2009:10-16).

The rationale for this article lies in the context of the lived experiences of the first author who had experienced the reality of being a woman, in both education and in society in general, in Malawi. These experiences stretched from Banda to Banda - Hastings Kamuzu Banda who reigned in a dictatorial manner over the country and women from 1964 to 1994 even forbidding them from wearing pants - and Joyce Banda who ruled as the democratically elected president from 2012-2014. Her experience resulted in two questions: How are women portrayed in Malawian Junior Secondary school History textbooks and why are they portrayed the way they are? The article is based on empirical research and employed feminist theory as the theoretical framework. All the visual images in the selected history textbooks were analysed quantitatively through visual content analysis and qualitatively using visual semiotic analysis.

Textbook production in Malawi is controlled by the government through the Ministry of Education. The latter controls the content, production, quality and availability of textbooks in schools. In terms of the production of textbooks, the Ministry of Education is responsible for publishing primary school textbooks by utilising its own employees in collaboration with the Ministry. However, the responsibility for publishing secondary school textbooks is left in the hands of private sector publishers who are guided by the curriculum provided by the government. These publishers commission individuals or teams of writers (preferably local) to write the books and the commissioning publishers concerned simply edit the drafts or manuscripts (Ministry of Education Science and Technology, 2006). The history textbooks we used in this article were published by Longman Malawi and Christian 


\section{Literature Association in Malawi.}

With regard to authorship of the textbooks, government policy as overseen by the Ministry of Education Science and Technology stipulates that any commercial publisher who develops manuscripts and provides publishing services is the author of the secondary school textbook. However, other publishers include names of individual writers as authors. This explains why two of the books we used in this article have Longman as both publisher and author while one indicated the name of the individual writer as author alongside the publisher. When the books have been produced by the publishers, they go through an evaluation procedure conducted by the Ministry of Education before they are approved for use in the schools. The textbooks that we analysed in this article were all approved by the Ministry of Education. The approved textbooks are announced to the schools and made available in various bookshops. Unlike in primary school secondary schools are provided with several options of approved textbooks from different publishers from which to choose. This means that several textbook titles for each subject can be approved for use in secondary schools and individual schools have the liberty to purchase and use any title from the list of approved texts. Currently there are three history textbooks for the junior level that have been approved for use in the schools.

The article is organised into five broad sections. In the first we introduce and outline the study. In the second we present the literature review and the theoretical framework for the study. This is followed by the research methodology and the presentation and discussion of the findings. In the conclusion we draw the article together.

\section{Literature review}

Textbooks are contentious in nature as they are a, “... representation of political, cultural, economic and political battles and compromises" and they are therefore extremely complex (Crawford, 2004:2). As such textbooks are symbolic representations of the world as well as the society in which we live (Sleeter \& Grant, 1991:78-109). Issues relating to gender and its depiction in textbooks is part of the complex symbolic representation of the world. Consequently much has been written over the past several decades about the visual portrayal of women in textbooks in general and in history textbooks specifically (O'Kelly, 1983:136-148; Sleeter \& Grant, 1991:78- 
109; Osler, 1994:219-235; Fournier \& Wineburg, 1997:160-185; Clark, Ayton, Frechette \& Keller, 2005:41-45; Chick, 2006:284-290; Schocker \& Woyshner, 2013:23-31).

In a study conducted in 1994, Osler analysed 36 history textbooks used in England by pupils aged 11-14. In her analysis she divided visual images into two groups, photographs and modern sketches and reconstructions. Osler concluded that women were under-represented in both categories. For instance, in every textbook, the number of photographs in which women appeared was less than those containing men. She concluded that the best balanced history textbook had almost twice as many photographs of men as of women and the least equitable texts contained a ratio of $26: 1$ of men to women respectively (Osler, 1994:219-235). Similarly, in the modern sketches and reconstructions, two textbooks had a ratio of 6:1 of men to women and in one textbook the proportion was 40:1. Even more telling was the fact that over half of the history textbooks analysed did not include any sketches and reconstructions of women. In her explanation of the under-representation and invisibility of women as historical characters Osler (1994:219-235) attributed it to early historians who did not consider topics involving women in their selection of subject matter. Consequently, the roles of women were downplayed visually and in written format. However, what Osler does deny is the argument that a lack of available sources is to blame for the underrepresentation of women in the visual images used in history textbooks. She rather attributes it to negligence on the part of writers and publishers due to the influence of the male dominated society in which they function. As evidence she points to the modern sketches and reconstructions which publishers use in which they have the liberty to produce reconstructions of the past that could include more women. Despite this opportunity, women are still under-represented in the history textbooks she studied.

Comparable conclusions to those of Osler were drawn by O'Kelly (1983:136148), in a content analysis of gender role images as depicted in fine art works related to the Gothic, Renaissance, Baroque and Modern periods. She noted that women represented $30 \%$ of the subjects in the works of art while men constituted $70 \%$. Furthermore, males made up $60 \%$ of portraits studied.

In a different geographical context, the United States of America (USA), similar findings were found to those of Osler and O'Kelly in terms of the under-representation of women in the visual images in textbooks. In a study of social studies textbooks used in USA schools from grade one to eight, 
Sleeter and Grant (1991:78-109) reported that women were represented in fewer visual images than men. More specifically women were depicted in 512 pictures while 855 featured men. Under-representation of women in visual images in USA history textbooks was also illustrated in studies by Clark, Ayton, Frechette and Keller (2005:41-45), Chick (2006:284-290), and Schocker and Woyshner (2013:23-31). In their study of 18 world history textbooks for high school students from the 1960s, 1980s and 1990s in the USA, Clark et al (2005:41-45) noted that only 368 pictures of women were named in the captions in contrast to 2167 images of men captioned with names. Similarly, Chick (2006:284-290), who analysed the K - 12 American history textbooks for gender balance, noted that all the three textbooks she studied contained significantly more males than females in the visual images. She reported that in the grade two textbook, there were 31 images of women in contrast to 89 of men, while in a grade 7-9 textbook women comprised 53 visual images and men 185 and a grade 9-12 textbook contained 46 pictures of females and 185 of men (Chick, 2006:284-290). Additionally, Schocker and Woyshner (2013:23-31) who studied one African American history textbook and two mainstream USA history textbooks for their representation of African American women revealed that African-American women were represented in lower percentages than men in the visual images in both sets of textbooks. Specifically, women were represented in only $14.4 \%$ of the images in the African-American themed history textbook. Similarly, the two mainstream American history textbooks comprised women in percentages of $44.6 \%$ and $34.1 \%$ only.

Although operating in different contexts Su (2007:205-237) in Taiwan, Schoeman (2009:541-556), Fardon and Schoeman (2010:307-323), Nene (2014:100-120) in South Africa and Muravyeva (2006:51-62) in Russia, reported similar results to those found in the USA and Europe about the under-representation of women in the visual and written texts. Schoeman (2009:541-556), for instance, reported that the content in the textbooks she studied under-represented women. This is evidenced by the fact that in the three textbooks she analysed, the ratios of male to female subjects were 22:3, 11:3 and 23:3 respectively (Schoeman, 2009:541-556). Furthermore, Fardon and Schoeman (2010:307-323) observed a similar pattern regarding the under representation of women in the exemplar South African school history textbook they analysed. In this book women were generally absent within the discursive presentation of the text and no reference to female characters was made in the content. 
A deeper reading of the literature was also necessary to understand how women were portrayed in terms of roles, activities and characteristics in the visual images in which they actually appeared. The literature reviewed indicated that women were visually portrayed in a variety of roles and activities but the majority of these were stereotypically feminine in nature (O’Kelly, 1983:136-148; Sleeter \& Grant, 1991:78-109; Osler, 1994:219235; Schrader \& Wotipka, 2011:68-88; Schocker \& Woyshner, 2013:23$31)$. Only on rare occasions were women portrayed in what can be regarded as stereotypically masculine roles and activities (O'Kelly, 1983:136-148; Sleeter \& Grant, 1991:78-109; Osler, 1994:219-235; Schocker \& Woyshner, 2013:23-31).

The traditional feminine roles and activities in which women are portrayed in history textbooks were evident in O'Kelly's (1983:136-148) study covering the Gothic, Renaissance, Baroque and Modern eras. Across these eras women were portrayed as mothers, wives, servants, peasants, seductresses, participants in orgies, victims of rape, singers, dancers, slaves, prostitutes, harem girls and models - all general stereotypical traditional female roles related to domestic work, motherhood and sex objects. Only on a few occasions were women shown in stereotypically masculine roles such as leading soldiers to victory, farming and bartending (O'Kelly, 1983:136-148). Similarly, Osler (1994:219-235), in her study revealed that photographs of women showed them predominantly engaged in domestic roles. For instance, women were portrayed in activities such as child minding and nursing babies, in family portraits with their husbands and children, spinning, working in the kitchen, being punished as scolds and as witches, dancing and as observers of scientific experiments. These activities are more stereotypically associated with women. Osler's (1994:219-235) study revealed only one woman, Queen Elizabeth I, was shown as a leader. However, a study by Schrader and Wotipka (2011:6888 ) in the USA revealed that the photographs in the textbooks they studied portrayed women in a slightly more nuanced manner - not only as victims of war, but also as active community members, factory workers and leaders. There thus seems to be a consensus among the various studies in the way roles and activities of women are reflected in history textbooks. Women are mainly presented in the stereotypically traditional and domestic roles except for in a few exceptional cases where they are portrayed in engaging in activities outside of what is deemed the norm. 
At this stage of the review it is necessary to point out that all the studies reviewed, bar the ones by Schoeman (2009:541-556), Fardon and Schoeman (2010:307-323) and Nene (2014), do not deal with the visual portrayal of women in history textbooks in an African context. In addition no study could be located that dealt with the visual portrayal of women in history textbooks in an African context outside of South Africa. This is the niche in knowledge to which this article hopes to contribute.

Based on the literature reviewed, it can thus be concluded that women as portrayed in the visual images in history textbooks are marginalised, and sometimes even excluded all together, as historical characters, underrepresented when compared to men, portrayed largely in stereotypical female roles and activities and mostly portrayed with stereotypically female character traits. A common explanation for the particular portrayal of women is the patriarchal view of women in society and hence in history and history textbooks (O'Kelly, 1983:136-148; Osler, 1994:219-235). Tetreault (1982:40-44; 1986:211-262) takes this argument even further and contends that this under-representation can be attributed to the fact that the conceptualisation of history itself excludes women. However, we argue that under-representation of women in the visual images in history textbooks, and how they are portrayed, is a complex problem which could not be explained by one single factor. Consequently our study drew on feminist theory as the theoretical lens through which to conceptually understand the visual portrayal of women in junior secondary Malawian history textbooks.

We drew on feminist theory because the study is concerned with women as the phenomenon of inquiry. This theory was deemed relevant because of its potential to explain the positions of women in society. Although the study does not per se inquire on issues of women in a societal context, but analyses their portrayal in the visual images in textbooks, the way women are viewed in society gets reflected in textbooks because the latter by nature are manifestations of the society they serve. They signify particular constructions of reality and reflect the values and aspirations of the society (Apple, 1991:2239; Apple \& Christian-Smith, 1991:1-21; Foster \& Crawford, 2006:1-23).

Feminism is based on a strong belief that women in society are subordinated, oppressed, disadvantaged and treated unequally in comparison to men and that their oppression is not legitimate, natural or justified in any way. The aim of feminism is to change this situation by ensuring equality between men and women (Bryson, 1992:163-241; Kenway \& Modra, 1992:138-166; 
Code, 1995:13-44; Brooks \& Hesse-Biber, 2007:1-24; Hannam, 2007:8-15). However, feminism does not only address issues of justice and equality, but also "offers a critique of male-dominated institutions, values and social practices that are oppressive and destructive" by using gender as a category of analysis (Mannathoko, 1992:71). Despite this general conclusion, some feminists argue that feminism does not only recognise sex or gender as the single source of power that subordinates and oppresses women (Beasley, 1999:62-64; Bryson, 1999:10-27; Hannam, 2007:8-15). As Hannam (2007:12) argues, "some feminists prioritised gender issues throughout their lives, while others shifted their focus on their political interests over time, in some periods prioritising the fight against racism or class exploitation rather than women's subordination to men". Therefore, oppression and subordination of women is an intersection of gender, race and class (Bryson, 1999:10-27). Consequently, based on this argument, our analysis of the portrayal of women in the visual images in textbooks will not only be limited to gender but will be extended to issues of race and class. Thus the use of feminist theory provided us with tools for analysing and understanding the portrayal of women in the visual images in the three textbooks studied.

Feminism, however, does not only halt at explaining the subordination and oppression of women but extends further to question and challenge the origins of these social injustices and unequal power relations. As such, feminists hold the conviction that the condition of women is socially constructed, and therefore, it can be changed (Hannam, 2007:8-15). The goal of feminism therefore is to end the subordination and oppression of women and bring social justice and change in their conditions. In this regard, feminism will not only provide reasons why women are portrayed in particular ways in the visual images but will also offer solutions to change the portrayal of women in the visual images in textbooks by ensuring equality. Hence, as Weedon (1987:5-25) argues, feminism is both theory and politics. She asserts that it is a theory because it has a set of beliefs or understandings concerning the cause of the subordination and oppression of women and offers suggestions on how change to bring equality and social justice can be achieved, and, it is political because it is aimed at changing existing oppressive power relations in society in order to achieve equality and justice for women. We will return to this in the discussion section of the article. 


\section{Research methodology}

The sample for our study consisted of all visual images containing people from three history textbooks which at face value might look dated but which are currently the only books used at junior secondary school level, the final compulsory schooling phase, in Malawi. The textbooks are:

- G Chiunguzeni, New junior history course 1 \& 2 (CLAIM, Longman Malawi, Lilongwe, 2006).

- $\quad$ Author/s unknown, Strides in history 1 (Longman Malawi, Lilongwe, 2003).

- Author/s unknown, Strides in history 2 (Longman Malawi, Lilongwe, 2003).

In this study, we refer to the New junior secondary history course $1 \& 2$ as Textbook A, Strides in history 1 as Textbook B and Strides in history 2 as Textbook C. This was done because it is more succinct for us to refer to the textbooks in this way while blunting any possible bias from us related to specific titles. These approved textbooks, in use across Malawi, were selected based on purposive and convenience sampling because of their relevance and availability for the study.

The data for our study was both generated and collected. It was generated by the publishers who produced the textbooks and collected by the researchers who bought the textbooks from bookshops. In agreement with Nicholls (2003:1-17), we wish to emphasise that attempting research in textbooks is not an easy undertaking because methodologies for analysis are not always well described. Consequently we tried to create workable instruments for analysing the visual images premised on our understanding of content and visual semiotic analysis.

We analysed all the visual images of each textbook separately starting with Textbook A and ending with Textbook C. The content analysis of the visual images was employed quantitatively with pre-set categories that were derived from the literature and the theoretical framework. This was done because with quantitative content analysis, categories for coding data are created depending on the key concepts of the phenomenon under study (Ary et al., 2002; Wilkinson \& Birmingham, 2003:67-78; Leavy, 2007:223-248). The instrument had two major categories with criteria under each category to guide us in the coding exercise. These categories were: 1 . representation of women in the visual images and 2, the manner in which women are portrayed in the visual images. We began our analysis with the category of the representation of women in visual images. This involved first counting all the visual images 
containing people in each textbook and then the visual images that portrayed women. Totals were recorded and the percentages of visual images portraying women were calculated. Additionally, for the visual images featuring women, we counted those that portrayed women only as well those that showed both men and women. Totals were again taken and percentages of visual images that portrayed women only and those that depicted both men and women calculated. The next step was to analyse the number of people in the visual images as well as those of women and men portrayed in each textbook. Totals were again recorded and percentages of women and men portrayed in the visual images calculated for each textbook.

After we completed the analysis of data for the first category, we moved to the second which was concerned with the type of visual images in which women were portrayed. We classified the visual images into single visual images showing one person, pairs and group visual images consisting of three or more people. We also categorised the visuals into those showing women only and those showing both men and women. We first counted the single visual images showing one person as well as those showing women only and men only. Totals were taken and percentages of single visual images of women only and of men only were calculated. Secondly we counted pair visual images depicting two people, then those portraying women only as well as both men and women. Totals were recorded and percentages of pair visual images of women only and both men and women were calculated. Thirdly we counted the total number of group visual images as well as those portraying women only as well as those portraying both men and women together. Finally percentages of group visual images portraying women only and men and women together were calculated.

After the content analysis of the visual images, which was undertaken quantitatively by means of descriptive statistics as explained above, we analysed the visual images qualitatively using visual semiotics. Semiotics is the study of signs in order to derive meaning from them (Hopkins, 1998:139-156; MacCannell, 1999:17-34; Harrison, 2003:46-40; Nelson, 2005:131-143; Rose, 2007:74-106; Parsa, 2012: 844-853). A sign is anything that stands for or represents something and it could be verbal or non-verbal such as written text and sound or visuals such as photographs and images (MacCannell, 1999:17-34; Bulut \& Yurdaisik, 2005:46-54; Rose, 2007:74-106; Parsa, 2012: 844-853). Semiotics is able to reveal meaning because signs by nature are made up of two components, the signifier and the signified (Kress \& 
Van Leeuwen, 1996:1-14; Rose, 2007:74-106; Parsa, 2012:844-853). It is through the systematic study of the signifiers in signs that meanings (the signified) are revealed or disclosed. The signifier is literally an object or word while the signified refers to the meaning or concept the signifier represents (Rose, 2007:74-106; Parsa, 2012: 844-853). Furthermore, meaning in visual semiotics is arrived at through use of denotations and connotations inherent in the images. This is because "signs are also both denotative and connotative" by nature (Parsa, 2012:849). In semiotics, the terms denotation and connotation describe the relationship between the signifier and the signified. Thus a signifier can disclose denotative or connotative meaning, or both, depending on the way the image or sign is made. Denotations give literal meaning of the image while connotations reveal hidden meaning in the sign which may be cultural or ideological (Parsa, 2012: 844-853). Visual semiotics therefore is the systematic study of visual images in order to expose the meaning that the images communicate (Kress \& Van Leeuwen, 1996:1-14; Rose, 2007:74106; Parsa, 2012: 844-853). Using this method we analysed only those visual images which featured women whether as individuals, in pairs with men or women and in groups either with men or women only.

Against this background we could now proceed to explain in detail how we conducted the visual semiotic analysis of the images of women contained in the three textbooks studied. Prior to conducting the visual semiotic analysis we developed an analytical instrument. As Morton (2006:21-37) argues, interpreting images requires the use of a tool which is guided by the background and purpose of the investigation. Since images as signs consist of signifiers and the signified (Kress \& Van Leeuwen, 1996:1-14; Rose, 2007:74-106; Parsa, 2012:844-853), we developed an instrument which would enable us to decode the signifiers and signified from the images in order to reveal the meaning implied in them. The instrument had three columns indicating sign (image), signifiers and the signified. The number of rows in the instrument varied depending on the number of visual images in each textbook. For instance, the analytical tool for Textbook A had only two rows because there were only two visual images showing women in this textbook, Textbook B included 23 rows while Textbook C had 11. Therefore three analytical instruments were developed for the three textbooks. During the analysis we looked for signifiers from the visual images guided by the following aspects contained in the table below. 
Image 1: Guidelines for visual semiotic analysis of the selected history textbooks

\begin{tabular}{|l|}
\hline Guidelines for visual semiotic analysis \\
\hline Roles and activities \\
Locus where the activities are performed \\
Positions of power and authority or status of women \\
Political, social and economic activities \\
Environment where women are portrayed \\
Race of women portrayed \\
Nationality and origin \\
Character traits \\
\hline
\end{tabular}

As with the content analysis explained above, the visual semiotic analysis of the images also progressed from Textbook A through B to C. The findings arrived at from this analysis were further analysed thematically and conclusions were drawn about the visual portrayal of women.

\section{Data presentation and findings}

As per our methodology as outlined above we started by counting the number of images in each textbook that featured women and men. This was done to determine the visual representation of women in visual images in the Malawian junior secondary history textbooks. The results were then presented in table format and expressed as percentages for the sake of readability. Thereafter the number of people in the visual images was counted and the totals for women and men were compared and contrasted.

\section{The representation of women and men in the visual images}

Textbook A (See Image 2) contained a total of 18 visual images of people. Of these only two featured women while 17 showed men. One group visual image was counted twice in the analysis. It was counted under visual images depicting women as well as under those showing men because it was a group visual image which contained both men and women. Statistically therefore, women are included in $11.1 \%$ of the visual images contained in this textbook. In contrast men appeared in a significant greater percentage $88.9 \%$ of the visual images. 
Image 2: Number of visual images featuring women

\begin{tabular}{|c|c|c|c|c|}
\hline $\begin{array}{c}\text { Total number of } \\
\text { visual images of } \\
\text { people }\end{array}$ & $\begin{array}{c}\text { Number of visual } \\
\text { images showing } \\
\text { women }\end{array}$ & $\begin{array}{c}\text { Percentage of visual } \\
\text { images showing } \\
\text { women }\end{array}$ & $\begin{array}{c}\text { Number of } \\
\text { visual images } \\
\text { showing men }\end{array}$ & $\begin{array}{c}\text { Percentage of } \\
\text { visual images } \\
\text { showing men }\end{array}$ \\
\hline 18 & 2 & $11.1 \%$ & 17 & $88.9 \%$ \\
\hline
\end{tabular}

Source: Textbook A.

The 18 visual images in Textbook A contained a total of 33 people. Only three of these were women while 30 were men. In terms of percentages, this means that only $9 \%$ of the people depicted in the visual images in this textbook are women while an overriding $91 \%$ are men (See Image 3). The conclusion to be drawn is simply women as historical characters are practically invisible in Textbook A.

Image 3: Number of women portrayed in visual images

\begin{tabular}{|c|c|c|c|c|c|}
\hline $\begin{array}{c}\text { Total number } \\
\text { of visual } \\
\text { images }\end{array}$ & $\begin{array}{c}\text { Total number } \\
\text { of people } \\
\text { portrayed }\end{array}$ & $\begin{array}{c}\text { Number } \\
\text { of women } \\
\text { portrayed }\end{array}$ & $\begin{array}{c}\text { Percentage of } \\
\text { women portrayed }\end{array}$ & $\begin{array}{c}\text { Number } \\
\text { of men } \\
\text { portrayed }\end{array}$ & $\begin{array}{c}\text { Percentage } \\
\text { of men } \\
\text { portrayed }\end{array}$ \\
\hline 18 & 33 & 3 & $9 \%$ & 30 & $91 \%$ \\
\hline
\end{tabular}

Source: Textbook A.

Textbook B contained 48 visual images of which 23 featured women while 41 showed men (See Image 4). As with the group visual image in Textbook A, group and pair visual images which portrayed both women and men were counted twice. They were counted under the category of visual images depicting women as well as under those showing men. This explains why the numbers of visual images showing women, and those featuring men, contradict the total number of visual images. Statistically, women were portrayed in $36 \%$ of the visual images analysed in this textbook and men in 64\%.

Image 4: Number of visual images featuring women

\begin{tabular}{|c|c|c|c|c|}
\hline $\begin{array}{c}\text { Total number of } \\
\text { visual images of } \\
\text { people }\end{array}$ & $\begin{array}{c}\text { Number of visual } \\
\text { images showing } \\
\text { women }\end{array}$ & $\begin{array}{c}\text { Percentage of } \\
\text { visual images } \\
\text { showing women }\end{array}$ & $\begin{array}{c}\text { Number of visual } \\
\text { images showing } \\
\text { men }\end{array}$ & $\begin{array}{c}\text { Percentage of } \\
\text { visual images } \\
\text { showing men }\end{array}$ \\
\hline 48 & 23 & $36 \%$ & 41 & $64 \%$ \\
\hline
\end{tabular}

Source: Textbook B.

The 48 visual images in Textbook B analysed contained a total of 251 historical characters (See Image 5). Out of this, 63 were women and 188 were men. Statistically women comprise only $25 \%$ of the people represented in 
the visual images while men comprised $75 \%$. This means that in comparison two-thirds more male historical characters than female ones appeared in Textbook B.

Image 5: Number of women depicted in visual images

\begin{tabular}{|c|c|c|c|c|c|}
\hline $\begin{array}{c}\text { Total number } \\
\text { of visual } \\
\text { images }\end{array}$ & $\begin{array}{c}\text { Total number } \\
\text { of people } \\
\text { portrayed }\end{array}$ & $\begin{array}{c}\text { Number } \\
\text { of women } \\
\text { portrayed }\end{array}$ & $\begin{array}{c}\text { Percentage } \\
\text { of women } \\
\text { portrayed }\end{array}$ & $\begin{array}{c}\text { Number } \\
\text { of men } \\
\text { portrayed }\end{array}$ & $\begin{array}{c}\text { Percentage of } \\
\text { men portrayed }\end{array}$ \\
\hline 48 & 251 & 63 & $25 \%$ & 188 & $75 \%$ \\
\hline
\end{tabular}

Source: Textbook B.

In Textbook C, of the 46 visual images analysed, 11 featured women while 45 showed men (See Image 6). Visual images which showed both men and women in groups and pairs were again counted twice - under those featuring women as well as those showing men. This explains why the total number of visual images analysed (46) does not tally with the sum total of visuals featuring women and men. The figures indicate that women featured in only $20 \%$ of the visual images in this History textbook while men featured in four times more in $80 \%$ of the images.

Image 6: Number of visual images featuring women

\begin{tabular}{|c|c|c|c|c|}
\hline $\begin{array}{c}\text { Total number of } \\
\text { visual images of } \\
\text { people }\end{array}$ & $\begin{array}{c}\text { Number of visual } \\
\text { images showing } \\
\text { women }\end{array}$ & $\begin{array}{c}\text { Percentage of } \\
\text { visual images } \\
\text { showing women }\end{array}$ & $\begin{array}{c}\text { Number of visual } \\
\text { images showing } \\
\text { men }\end{array}$ & $\begin{array}{c}\text { Percentage of } \\
\text { visual images } \\
\text { showing men }\end{array}$ \\
\hline 46 & 11 & $20 \%$ & 45 & $80 \%$ \\
\hline
\end{tabular}

Source: Textbook C.

The 46 visual images analysed comprised a total of 172 people (See Image 7). However, only 29 were women and 143 were men. Women thus made up only $17 \%$ of the historical characters visually represented in in this publication while men comprised $83 \%$. This meant that in Textbook $\mathrm{C}$ women were totally underrepresented in comparison to men.

Image 7: Number of women portrayed in visual images

\begin{tabular}{|c|c|c|c|c|c|}
\hline $\begin{array}{c}\text { Total number } \\
\text { of visual images } \\
\text { analysed }\end{array}$ & $\begin{array}{c}\text { Total number } \\
\text { of people } \\
\text { portrayed }\end{array}$ & $\begin{array}{c}\text { Number } \\
\text { of women } \\
\text { portrayed }\end{array}$ & $\begin{array}{c}\text { Percentage } \\
\text { of women } \\
\text { portrayed }\end{array}$ & $\begin{array}{c}\text { Number } \\
\text { of men } \\
\text { portrayed }\end{array}$ & $\begin{array}{c}\text { Percentage } \\
\text { of men } \\
\text { portrayed }\end{array}$ \\
\hline 46 & 172 & 29 & $17 \%$ & 143 & $83 \%$ \\
\hline
\end{tabular}

Source: Textbook C. 
From the above it is thus clear that women are seriously under-represented as historical role players in the visual images in all the three textbooks studied. Of the 160 visual images across the three junior secondary history textbooks only 36 contained women. This is equal to only $22 \%$ of the visual images containing women in some shape or other. The under representation of women in visual images becomes even more stark when it is considered that out of the total of 456 people portrayed in the visual images only 95 or $20 \%$ are women.This under-representation renders women almost invisible in the visual images and portrays them as marginal to history which implies little contribution to history by women. The male dominance of the visual images paints a strong picture of women being subordinated, oppressed, disadvantaged and treated unequally as historical characters.

\section{The manner in which women are portrayed in visual images}

The next step in our analysis was to reach an understanding of the manner in which the 95 women that do appear in the visual images in the history textbooks analysed were portrayed. This was done based on three categories the portrayal of women in pairs, as a group or as individuals. The purpose of this section of the analysis was to develop a deeper understanding of, not only the relational portrayal of women in visual images in the analysed textbooks, but also to what this would reveal in terms of historical standing.

In Textbook A women were not portrayed in any visual images in pairs, be it of women only or of a woman and a man together. Women were only portrayed in one visual image in a group context - two women alongside eight men. Women only featured in one individual image as an individual (See Image 8).

Image 8: Manner in which women are portrayed in visual images

\begin{tabular}{|c|c|c|c|}
\hline $\begin{array}{c}\text { Manner portraying } \\
\text { women }\end{array}$ & $\begin{array}{c}\text { Number of visual } \\
\text { images showing } \\
\text { women per manner }\end{array}$ & $\begin{array}{c}\text { Number of visual images } \\
\text { showing women only per } \\
\text { manner }\end{array}$ & $\begin{array}{c}\text { Number of visual images } \\
\text { showing women and men } \\
\text { together per manner }\end{array}$ \\
\hline Pair & 0 & 0 & 0 \\
\hline Group & 1 & 0 & 1 \\
\hline Single & 1 & 1 & N/A \\
\hline
\end{tabular}

Source: Textbook A.

An analysis of all the visual images in Textbook B indicated that there were two pair visual images which featured women. However, both these visual 
images portrayed a woman together with a man. Of the 19 visual images portraying women in groups, 18 depicted women together with men. Only one visual image of women only in a group featured in Textbook B. In terms of portraying women as self-standing individuals, only two such images were identified (See Image 9).

Image 9: Manner in which women are portrayed in visual images

\begin{tabular}{|l|c|c|c|}
\hline $\begin{array}{c}\text { Manner portraying } \\
\text { women }\end{array}$ & $\begin{array}{c}\text { Number of visual } \\
\text { images showing women } \\
\text { per manner }\end{array}$ & $\begin{array}{c}\text { Number of visual images } \\
\text { showing women only per } \\
\text { manner }\end{array}$ & $\begin{array}{c}\text { Number of visual images } \\
\text { showing women and men } \\
\text { together per manner }\end{array}$ \\
\hline Pair & 2 & 0 & 2 \\
\hline Group & 19 & 1 & 18 \\
\hline Single & 2 & 2 & N/A \\
\hline
\end{tabular}

Source: Textbook B.

Analysing the visual images in Textbook $\mathrm{C}$ as per the identified categories revealed that women appeared paired with a man on two occasions, and in ten group visual images. Out of these nine showed women together with men. Not a single woman was deemed worthy for portrayal as an individual self-standing historical character in Textbook C (See Image 10).

Image 10: Manner in which women are portrayed in visual images

\begin{tabular}{|c|c|c|c|}
\hline $\begin{array}{c}\text { Manner } \\
\text { portraying women }\end{array}$ & $\begin{array}{c}\text { Number of visual images } \\
\text { showing women per } \\
\text { manner }\end{array}$ & $\begin{array}{c}\text { Number of visual images } \\
\text { showing women only } \\
\text { per manner }\end{array}$ & $\begin{array}{c}\text { Number of visual images } \\
\text { showing women and men } \\
\text { together per manner }\end{array}$ \\
\hline Pair & 1 & 0 & 1 \\
\hline Group & 10 & 1 & 9 \\
\hline Single & 0 & 0 & N/A \\
\hline
\end{tabular}

Source: Textbook C.

Several conclusions can be gleaned from the manner in which the 95 women that do appear in visual images in the three Malawian junior secondary history textbooks are portrayed. First of these is that it is rare for women to appear in visual images without men being present. The fact that women are portrayed in the presence of men in almost every visual image across all three textbooks reduces them to historical actors generally only worthy of appearing alongside men as subordinates as if reliant on the agency of the latter. This means that only in exceptional cases were women deemed historically worthy enough by the textbook producers to be portrayed as individuals or alongside other women. The manner in which women were portrayed not only spoke to underrepresentation but also to a marginalisation and oppression of them as historical characters. 


\section{The identity of women portrayed in the visual images}

The third stage of our analysis entailed a visual semiotic analysis of the visual images containing women. The purpose of this was to obtain a deeper understanding, beyond the numbers, of the manner in which the 95 identified women were portrayed in the analysed textbooks. In the first level of analysis emphasis was placed on the identity attributed to the women.

In Textbook A women were only portrayed in two images: as the Greek goddess Athena and as part of a slave caravan. Athena is European and of high social status in Greek religion (See Image 11) while the female slaves are black African women who are portrayed as being powerless people and victims (See Image 12).

Image 11: The Greek goddess Athena

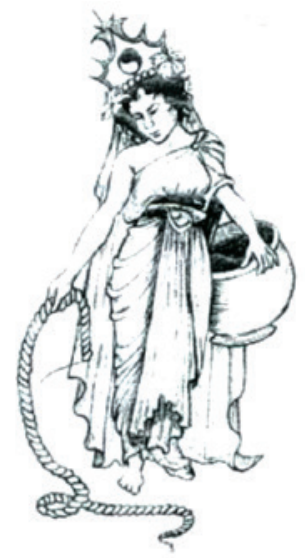

Source: Textbook A (p. 53).

Image 12: A slave caravan

Captives being taken to a slave market. Notice the captive about to be hacked to death by a slave raider

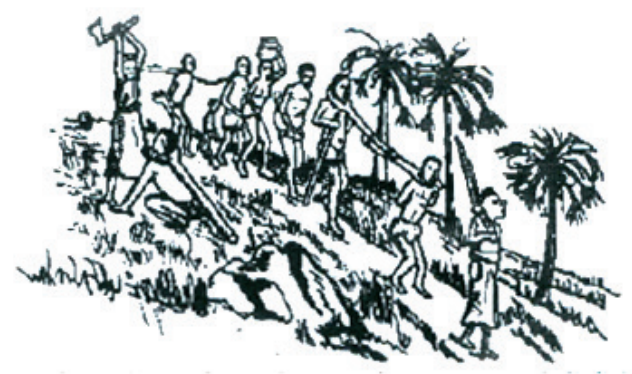

Source: Textbook A (p. 110). 
Textbook B proved to be the richest of all three analysed textbooks in terms of visual images' depiction of women. The 23 images featuring 63 women portrayed women in an array of identities. Some were portrayed as queens, angels, and as officials at a court meeting. Others were shown as school girls; an elderly local woman; mothers; wives; subsistent farmers; a tourist; huntergatherers (See Image 13); business women (See Image 14); and slaves. The vast majority of the women portrayed as historical characters in the visual images in Textbook B were ordinary women who held a lower socio-political status in society. The exception being the handful portrayed as queens, angels and officials at a political court meeting. At least in terms of the queens they were for the most part significant because of their betrothal to a king. Race was clearly an issue in the identity of the women portrayed with black women being reduced to more subservient roles such as slaves and an old woman for example. In contrast white women filled roles such as being a businesswoman (See Image 14). What also emerged from the semiotic analysis was that of the black women depicted in the visual images very few were clearly recognisable of Malawian origin - sharp commentary on how women of the country which the book was aimed at were viewed as historical characters.

Image 13: Women portrayed as wives and mothers in a Khoisan hunter-gatherer context

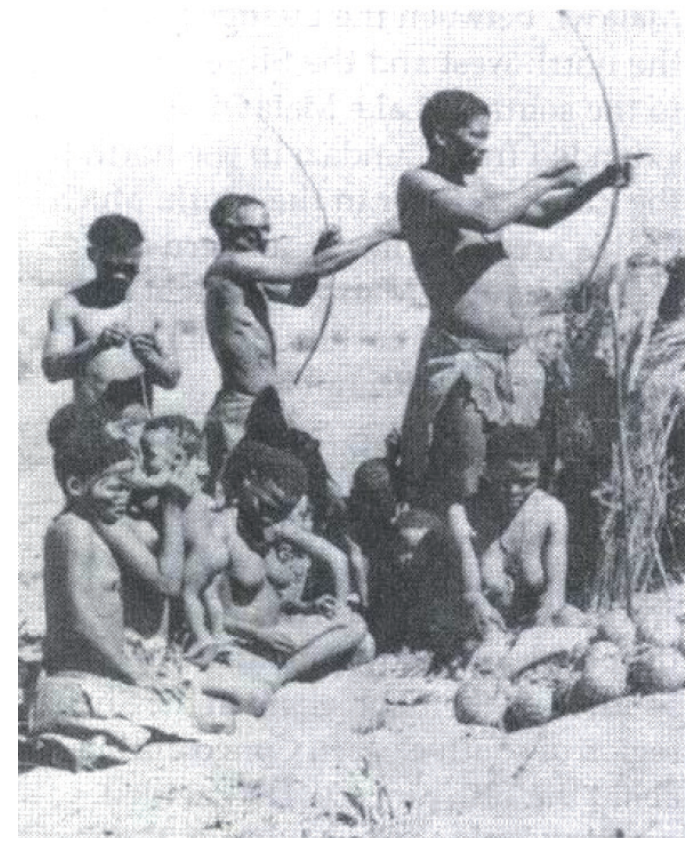

Source: Figure 9.3, Textbook B (p. 106). 
Image 14: A woman portrayed in a business activity A scene of daily city life in ancient Rome

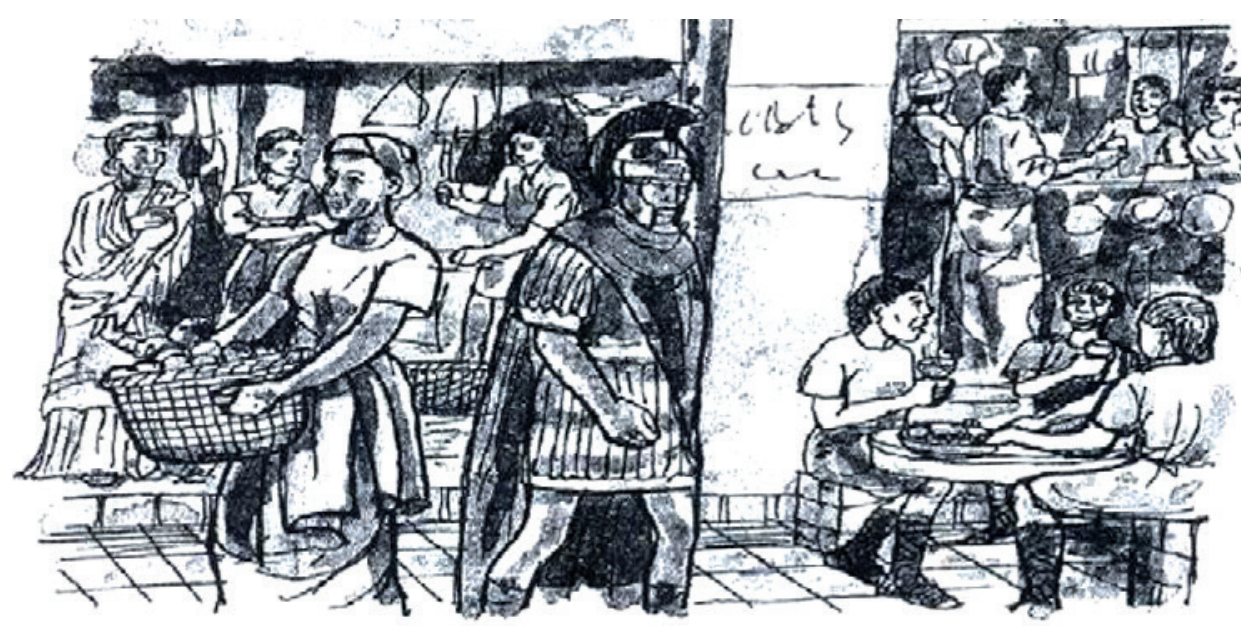

Source: Figure 11.6, Textbook B (p. 138).

The 11 images in Textbook $\mathrm{C}$ that portrayed women contained 29 in total. In these images women were portrayed as having multifarious identities. Some were portrayed as country representatives at the Pan-African Conference, wage labourers picking cotton in a plantation and school girls celebrating the attainment of freedom and justice. Other women portrayed in the visual images were the Virgin Mary (See Image 15); women in a mob celebrating the opening of the railway; spinners in a textile industry (See Image 16); women as slaves and mothers taking care of their children. The women portrayed in the visual images in Textbook $\mathrm{C}$, are except for the Virgin Mary and the women depicted attending the Pan-African Conference, ordinary women who populate the lower rungs of the socio-political ladder. Race also seems to be a factor in the identities attributed to women via the visual images as black women were seldom portrayed as being powerful historical actors. 
Image 15: Women as mothers and holy figures The Virgin of the Rocks by Leonardo da Vinci
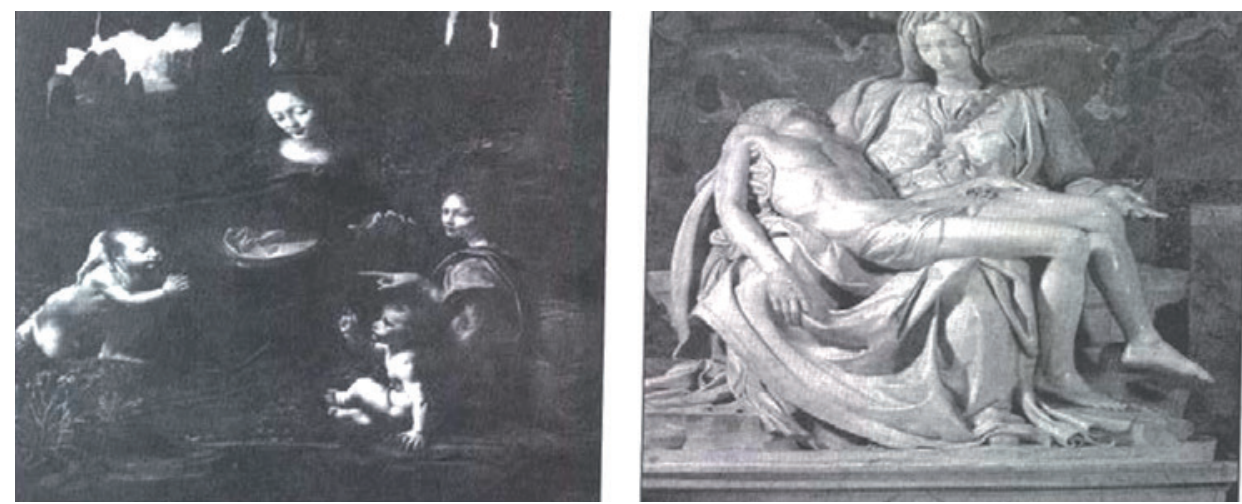

Source: Figure 3.3-3.4, Textbook C (p. 25).

Image 16: Women in an economic activity as spinners

The interior of a 19th century textile mill

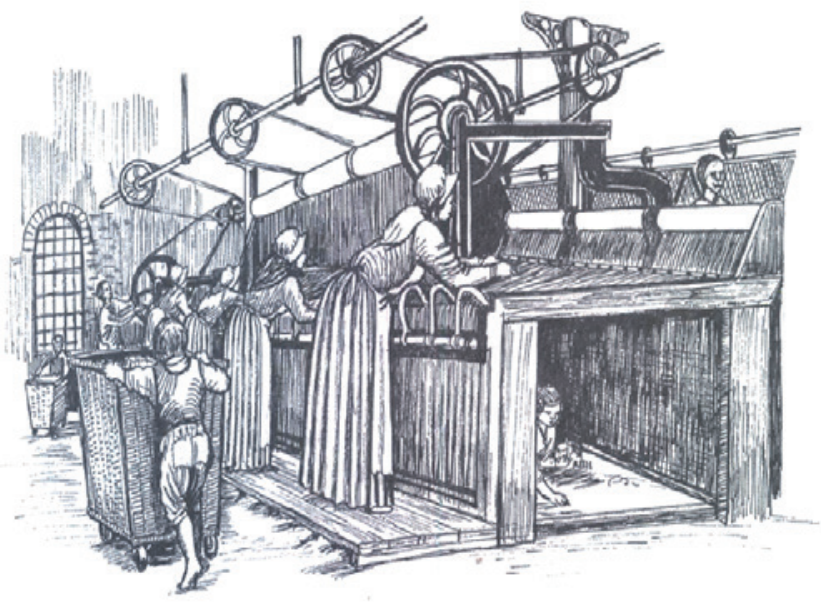

Source: Figure 5.8, Textbook C (p. 47).

Already in the earlier analysis it was established that women portrayed in the visual images in the three Malawian junior secondary history textbooks are under-represented, relegated to the margins of history, supressed, subordinate to men and disadvantaged as historical characters. The analysis in this section provided a deeper and more nuanced understanding of how the women were portrayed by focussing on the identities attributed to women as historical 
characters via the visual images. What stood out were the multifarious identities attributed to women. Apart from identities as mothers and wives they were also occasionally portrayed as religious and celestial figures, and associated with royal households. In terms of economic identities women were portrayed as weavers, businesswomen and subsistence farmers - for the most part labouring away in positions of little economic power. Politically, the pattern is generally the same with some having power by dint of their relationships with male figures such as the Virgin Mary and her relationship with Jesus. Socially, both race and class were important identity forming factors. Although less of the portrayed women are white they were invariably portrayed as having more agency by dint of being tourists, goddesses and businesswomen. What was particularly noticeable is the marginalisation of Malawian women as historical characters, both numerically and in terms of identity associated, in the visual images in all the three textbooks. This happened despite the fact that the books were produced for consumption in Malawian schools.

\section{The roles and activities in which women are portrayed}

In the final analysis section we will engage, based on our visual semiotic analysis, with the roles and activities in which women are portrayed in the three textbooks. In Textbook A there were only two visual images that included women. The visual image of Athena positioned her in a leadership role and as a divine leader in Ancient Greek religion. Besides the divine role, Athena was also portrayed in activities associated with domestic life. This was evidenced by the fact that she was portrayed carrying a pot in her right hand which signifies cooking, fetching water and being responsible for food. This portrays her in domestic roles which are stereotypical roles for women in society and serve to undermine her celestial leadership role (See Image 11). The second visual image in this book, of slaves being led to the market, revealed that in their role of being slaves, the women were also portrayed as mothers responsible for looking after children and as the custodians of food. In that visual image one slave woman was depicted carrying a baby. Another woman was portrayed carrying a load on her head which looked like a basket of food (See Image 12). This portrayed the women, in spite of being enslaved, in both reproductive and domestic roles and activities.

The analysis of the visual images in Textbook B revealed the portrayal of women in a variety of roles and activities. For instance, in some visual 
images black women were portrayed as wives and mothers and in a variety of domestic roles such as taking care of the home, processing grain, being custodians of food and narrating oral tradition. All the women portrayed in these roles were exclusively black (See Image 13). The exception was a single image in which two women were portrayed in the economic activity of selling goods at a market. In contrast women portrayed in productive activities outside the house were invariably white women (See Image 14). Thus white women, despite their limited representation in the visual images in Textbook B, are portrayed in a more economically engaging position than their black counterparts. Additionally, religious roles such as being angels or going to the mosque for prayers were also attributed to women. A minority of the the visual images also portrayed women in leadership roles and positions of authority such as queens and participants in a political court meeting. However, in most cases these roles could not be separate from their being related to men as mothers or wives which served to emphasise the domestic and reproductive roles they need to fulfil.

In the third book, Textbook C, some women were likewise portrayed in stereotypical roles as mothers and wives (See Image 15). Women were, however, also economically portrayed as labourers picking cotton, spinning in a textile mill (See Image 16) and working as slaves on a sugar cane plantation. Besides the manual labour economic activities, women were also portrayed in political activities as participants in a Pan-African Conference held in Manchester in 1945, celebrating the opening of the Stockton-Darlington railway in Britain during the period of the Industrial Revolution and celebrating the attainment of freedom and justice in an African state. On the whole, in terms of the roles and activities attributed to women in Textbooks $\mathrm{C}$, they were portrayed in a diversity of roles when compared to Textbooks A and B.

Across the three analysed history textbooks women were visually portrayed in domestic and reproductive roles as mothers and wives taking care of children and food. Even powerful figures could not escape such roles being attributed to them. Economically women were, for the most part, portrayed as being active as industrial and agricultural workers and homemakers. Spiritual and religious roles were also, by means of the visual images, attributed to women. However, across all three books an undercurrent did exist which served to challenge the stereotypical roles and activities attributed to women by portraying them as participants in the political process, celebrators and protestors. But these roles were underdeveloped and did not stray far from stereotypical thinking which 
attributes especially celebrating and protesting to women. What also became clear was that the roles and activities in which women were portrayed had a certain racial bias with white women, for the most part, shown to engage in less stereotypical activities such as being tourists and businesswomen.

\section{Discussion}

Having engaged with how women are portrayed in the visual images in Malawian junior secondary history textbooks we now turn to why they were portrayed the way they were. The visual content and visual semiotic analysis employed have produced firm findings and these will be engaged with by discussing the two key concepts of marginalisation and stereotyping.

The representation of women and also the manner in which they were portrayed pointed to the marginalisation of women as historical characters. One such form of marginalisation was through under-representation. Numerically remarkably fewer women than men appeared in the visual images rendering them almost invisible at times. However, this marginalisation through under-representation is not unique to this Malawian-based study and resonates with a range of other studies conducted in countries across the globe. Research conducted by Osler (1994:219-235) in England, Schoeman (2009:541-556) in South Africa and Schoker and Woyshner (2013:23-31) in the USA, to mention just a few, bears out this unequal treatment. Numerical under-representation of women in the visual images is directly linked to the manner in which they were portrayed in the three history textbooks. Women were rarely portrayed on their own as individuals, in groups or in pairs. They for the most part appeared in visual images alongside men. The worst in this regard was Textbook $\mathrm{C}$ which did not contain a single visual image of a woman on her own while textbook $\mathrm{A}$ had a single visual image of an individual woman. The fact that women were not portrayed visually on their own marginalises them because it firstly denies their agency as historical actors who were capable of initiating events and secondly associates their appearance in visual images being dependent on men.

Singularly the most subordinated, oppressed and disadvantaged women in the textbooks were Malawians - the populace at whom the books were aimed. They hardly featured and when they did it was generally as historical characters operating on the very margins of history. They were thus portrayed as people who had contributed little to the history of their society. The situation in the 
Malawian history textbooks studied raises a question as to why Malawian women as historical characters are marginalised in history textbooks of their own country. We would argue that the marginalisation of Malawian women reflects the patriarchal nature of Malawian society and the textbooks analysed are mirrors of the society they serve (Apple \& Christian-Smith, 1991:1-21; Foster \& Crawford, 2006:1-23). This finding, when viewed in the broader context of how other black women were visually portrayed in the textbooks, is supported by the study by Schocker and Woyshner (2013:23-31) as well as propositions by black feminists who argue that black women are not only oppressed by their gender but also because of their race (Hooks, 2001:33-44).

The marginalisation of women in the visual images analysed could be understood in the light of feminism arguments that traditions and customs that exist in society create barriers for women to participate equally with men in the public world beyond the home and family (Beasley, 1999:62-64; Bryson, 1999:10-27). Subsequently we would argue that women in the past have been barred by deep-rooted customs and traditions from participating fully in the public domain, not only in Malawi but across the globe, with the result that they were omitted from much of history and hence would not appear in most visual images in history textbooks. In addition, the marginalisation of women in the visual images reflects patriarchal beliefs about women in the past as well as present societies.

Like marginalisation, stereotyping of women in the visual images also manifested itself in various ways. One of the clearest indicators of stereotyping was the persistent portrayal of women as wives and mothers surrounded by men and children. This resonates with results of history textbook studies conducted in other parts of the world by, amongst others, Osler (1994:219235) and O'Kelly (1983:136-148). O'Kelly in her research on fine art history textbooks found that women were predominantly portrayed as wives and mothers. Similarly Osler found that women in the visual images in the history textbooks she analysed were portrayed with their husbands and children which implies motherhood, being wives and fulfilling reproductive roles. The stereotypical portrayal of women as wives and mothers is a reflection of the patriarchal expectation of the role of women in society, not only in Malawi, but also in other countries. As Lerner (1993:1-74), argues, in a patriarchal society, women are expected to marry and bear children as they are the nurturers and this is regarded as the primary role of all women regardless of race, class, nationality or continent. These are the roles in which women 
as a class have primarily and mainly participated most historically and still continue to do so in the present. In the Malawian textbooks analysed these roles were overemphasised to the extreme and women were not, unlike in the study by O'Kelly (1983:136-148), portrayed as sexually deviant in any manner.

The stereotyping of women and their roles and activities also manifested itself in their portrayal in domestic roles and activities and as performers of menial manual labour. However, this finding is not unique to our study and echoes the results of studies by O'Kelly (1983:136-148), Osler (1994:219$235)$ and Nene (2013:100-120) where women were portrayed as amongst others farming, working in the kitchen and engaged in other housework. Therefore, this study confirms the stereotypical portrayal of women in domestic roles as found in international studies. As with reproductive roles, domestic roles are regarded as the primary responsibility of women in a patriarchal society because of the division of gender roles it perpetuates. Feminist theorists attribute the portrayal of women in domestic roles as a reflection of patriarchal stereotypes about the roles of women in society, regardless of differences in race, nationality or continent (Beasley, 1999:6264; Bryson, 1999:10-27). Lerner (1993:1-74) argues that patriarchy believes that because of their nurturing role, women are meant for sustenance of daily life. This explains why women in patriarchal societies such as Malawi are cast into domestic roles as it is these activities which maintain society through provision of food, care and support in families.

Some women were, however, visually portrayed as exceptional historical characters. These are women who were portrayed beyond stereotypical female roles but as people with agency, capable of remarkable achievements and being powerful in their own right. An example is the female pharaoh Hatshepsut of Ancient Egypt. She was portrayed as a powerful ruler who governed for 20 years, thus an exceptional historical character. Although the portrayal of women as exceptions in for example political leadership seems to challenge patriarchal ideology which associates leadership with men and not women, we would argue that patriarchy still holds sway because the number of women portrayed in such positions is insignificant and unequal when compared to men and the majority of women portrayed in the textbooks. Furthermore, women were frequently portrayed as being exceptional however, women, like the Virgin Mary for example, achieved such positions by dint of their relationship to men. However, what the portrayal of women in leadership 
positions does is to underpin feminist views that women are as capable as men and where they appear inferior, it is because of their upbringing and lack of education and not due to nature (Beasley, 1999:62-64; Bryson, 1999:10-27; Abbott et al., 2005:16-56). Their oppression as historical characters is therefore not legitimate, natural or justified in any way. Despite this assertion, we would argue that the fact that only a few women are portrayed in exceptional roles in the visual images in the textbooks studied reflects a patriarchal view of the potential of women on the part of the customs and traditions of the society that produced these books.

\section{Conclusion}

At the outset of this article we highlighted the powerful status of visual images and that the act of seeing could be equated to believing. In conclusion we would argue that both these ideas hold true. The findings of this study highlighted the marginalisation and stereotyping of women as portrayed in the visual images in the three textbooks analysed. Considering the powerful nature of textbooks and visual images this constitutes a strong societal message to the end users of these publications and Malawian women respectively on what to believe in history. Simultaneously the findings point to the fact that women, as historical characters in junior secondary Malawian history textbooks are, and must be seen and believed to be subordinate, and not equal to men.

In terms of the broader research picture the portrayal of women in the visual images in the textbooks analysed resonates with similar studies conducted elsewhere. This leads us to conclude that women in visual images in history textbooks in different geographical and political context are generally treated in a similar manner. Emanating from an African context this article adds to the existing body of knowledge in this regard for no such study has been conducted in Africa outside of South Africa before. As such, this article contributes to the literature on the portrayal of women in history textbooks. More specifically it confirms the international literature on the visual portrayal of women in an African context and in so doing fills an existing niche.

What this study also confirmed is that the visual portrayal of women in history textbooks are afflicted broadly speaking, be it in Africa or elsewhere, by the same forces of patriarchy. In the case of Malawi, more specifically, this reflects a societal view of women, and women in history, deeply rooted in the 
society that produced these books. Hopefully, this article can contribute to challenging the patriarchal status quo in terms of how women are portrayed in history textbooks and in so doing give meaning to the countless gender equality policies recently adopted in Malawi. This in itself is the firmest recommendation this article makes.

\section{References}

Abbott, P, Wallace, C, \& Tyler, M 2005. An introduction to sociology: Feminist perspectives. London: Routledge.

Apple, MW \& Christian-Smith, LK 1991. The politics of the textbook. In: MW Apple \& LK Christian-Smith (eds.). The politics of the textbook. New York: Routledge.

Apple, MW 1991. The culture and commerce of the textbook. In: MW Apple \& LK Christian-Smith (eds.). The politics of the textbook. New York: Routledge.

Beasley, C 1999. What is feminism? An introduction to feminist theory. London: Sage.

Berger, AA 1989. Seeing is believing: An introduction to visual communication. Mountain View: Mayfield Publishing Company.

Brooks, A \& Hesse-Biber, SN 2007. An invitation to feminist research. In: SN Hesse-Biber $\&$ PL Leavy (eds.). Feminist research practice; A primer. Thousand Oaks: SAGE Publications.

Bryson, V 1992. Feminist political theory: An introduction. New York: Paragon House.

Bryson, V 1999. Feminist debates: Issues of theory and political practice. London: MacMillan.

Bulut, T \& Yurdaisik, A 2005. Visual semiotics and interpretation in the television commercial. $A S / S A, 6(16): 46-54$.

Chick, KA 2006. Gender balance in K-12 American history textbooks. Social Studies Research and Practice, 1(3):284-290.

Clark, R, Ayton, K, Frechette, N \& Keller, PJ 2005. Women of the world, re-write. Social Education, 69(1):41-45.

Code, L 1995. How do we know?: Questions of method in feminist practice. In: S Burt \& L Code (eds.). Changing methods: Feminists transforming practice. Petersborough: Broadview Press. 
Crawford, K 2004. Inter-cultural education: the role of school textbooks analysis in shaping a critical discourse on nation and society. Paper presented at the Pacific Circle Consortium 27th Annual Conference, 21-23 April, 2004, Hong Kong Institute of Education.

Fardon, J \& Schoeman, S 2010. A feminist post-structuralist analysis of an exemplar South African School history text. South African Journal of Education, 30:307-323.

Foster, S \& Crawford, K 2006. The critical importance of history textbook research. In: $S$ Foster \& K Crawford (eds.). What shall we tell the children?: International perspectives on school history textbooks. Greenwich: Information Age Publishing Inc.

Fournier, JE \& Wineburg, SS 1997. Picturing the past: Gender differences in the depiction of historical figures. American Journal of Education, 105(2):160-185.

Hannam, J 2007. Feminism. London: Pearson.

Harrison, C 2003. Visual social semiotics: Understandig how still images make meaning. Technical Communication, 50(1):46-60.

Hooks, B 2001. Black women shaping feminist theory. In: B Kum-Kum (ed.). Feminism and race. Oxford: Oxford University Press.

Hopkins, J 1998. Commodifying the countryside: Marketing myths of reality. In: C Butler, CM Hall \& J Jenkins (eds.). Tourism and recreation in rural areas. Chichester: John Wiley \& Sons.

Kenway, J \& Modra, H 1992. Feminist pedagogy and emancipatory possibilities. In: C Luke \& J Gore (eds.). Feminisms and critical pedagogy. London: Routledge.

Kress, G \& Van Leeuwen, T 1996. Reading images: The grammar of visual design. London: Routledge.

Leavy, PL 2007. Feminist practice of content analysis. In: SN Hesse-Biber \& PL Leavy (eds.). Feminist research practice: A primer. Thousand Oaks: Sage.

Lerner, G 1993. The creation offeminist consciousness: From the middle ages to eighteen-seventy. New York: Oxford University Press.

MacCannell, D 1999. The tourist: A new theory of the leisure class. Berkeley: University of California Press.

Mannah, S 2008. The experiences of women leaders in the South African Democratic Teachers' Union (SADTU). Unpublished DEd thesis. Durban: University of KwaZulu-Natal. 
Mannathoko, C 1992. Feminist theories and the study of gender issues in Southern Africa. In: K Meena (ed.). Gender in Southern Africa: Conceptual and theoretical issues. Harare: SAPES Books.

Morton, J 2006. The integration of images into architecture presentations: a semiotic analysis. Art, Design \& Communication in Higher Education, 5(1):21-37.

Muravyeva, MG 2006. Shaping gender and national identity through Russian history textbooks on world history. Yearbook of the International Society for Didactics of History. 2005:51-62.

Nelson, V 2005. Representation and images of people, place and nature in Grenada's tourism. Geografiska Annaler, 87B(2):131-143.

Nene, NP 2014. An analysis of the visual images of women in Grade 12 South African history textbooks. Unpublished M.Ed dissertation. Pinetown: University of KwaZuluNatal.

Nicholls, J 2003. Methods in school textbook research. International Journal of Historical Learning, Teaching and Research, 3(2):1-17.

O'Kelly, CG 1983. Gender role stereotypes in fine art: Content analysis of art history books. Qualitative Sociology, 6(2):136-148.

Osler, A 1994. Still hidden from history?: The representation of women in recently published history textbooks. Oxford Review of Education, 20:219-235.

Parsa, AF 2012. Visual semiotics: How still images mean? : interpreting still images by using semiotic approaches. Available at http://akademik.maltepe.edu.tr/osmanurper/ g\%F6rselimajy\%F6n/visual\%20semiotics\%20how\%20still\%20images\%20 mean.pdf. Accessed on 11 April 2012.

Rose, G 2007. Visual methodologies: An introduction to the interpretation of visual materials. London: Sage Publications.

Schocker, JB \& Woyshner, C 2013. Representing African American women in U.S. history textbooks. The Social Studies, 104(1):23-31.

Schoeman, S 2009. The representation of women in a sample of post-1994 South African school history textbooks. South African Journal of Education, 29:541-556.

Schrader, CE \& Wotipka, CM 2011. History transformed?: Gender in World War II narratives in U.S. history textbooks, 1956-2007. Feminist Formations, 23(3):68-88. 
Sleeter, CE \& Grant, CA 1991. Race, class, gender and disability in current textbooks. In: MW Apple \& LK Christian-Smith (eds.). The politics of the textbook. New York: Routledge.

Su, Y 2007. Ideological representations of Taiwan's history: An analysis of elementary social studies textbooks, 1078-1995. Curriculum Inquiry, 37(3):205-237.

Tetreault, MKT 1982. The treatment of women in U.S. history high school textbooks: a decade's progress. Women's Studies Quarterly, 10(3):40-44.

Tetreault, MKT 1986. Integrating women's history: The case of United States history high school textbooks. The History Teacher, 19(2):211-262.

Weedon, C 1987. Feminist practice and poststructuralist theory. Oxford: Basil Blackwell.

Wilkinson, D \& Birmingham, P 2003. Using research instruments: A guide for researchers. London: RoutledgeFalmer.

Zeegen, L 2009. What is Illustration? Switzerland: RotoVision Publications. 